\title{
Across Iceland
}

\section{Author(s): Karl Grossmann}

Source: The Geographical Journal, Vol. 3, No. 4 (Apr., 1894), pp. 261-279

Published by: geographicalj

Stable URL: http://www.jstor.org/stable/1773690

Accessed: 19-06-2016 18:17 UTC

\section{Your use of the JSTOR archive indicates your acceptance of the Terms \& Conditions of Use, available at}

http://about.jstor.org/terms

JSTOR is a not-for-profit service that helps scholars, researchers, and students discover, use, and build upon a wide range of content in a trusted digital archive. We use information technology and tools to increase productivity and facilitate new forms of scholarship. For more information about JSTOR, please contact support@jstor.org.

The Royal Geographical Society (with the Institute of British Geographers), Wiley are collaborating with JSTOR to digitize, preserve and extend access to The Geographical Journal 


\section{The}

\section{Geographical Journal.}

No. 4.

APRIL, 1894.

VoL. III.

\section{ACROSS ICELAND.}

By KARL GROSSMANN, M.D., F.R.C.S.E.*

IT may appear, at first glance, a superfluous task to lay before this Society an account of a journey in Iceland, comprising, as it does to a great extent, ground that has been traversed before. Accounts of Icelandic travelling are by no means scanty; indeed, it almost looks as though a visit to Iceland is necessarily followed by a more or less violent attack of the furor scribendi, a complaint from which usually not even those escape who-as Sir Richard Burton somewhat disrespectfully expresses it -have only "done the cockney trip to the Geysirs," and possibly to Hekla. If in spite of this I think it worth while to bring forward my own experiences, I am led by the following considerations.

First of all, the abundance of interesting physiographical features which Iceland presents is surprising. These are, however, not always accessible, and even the most careful and able observer may miss what another traveller can hardly fail to notice without any effort under more favourable conditions. A great deal has to be left to chance, and under this chapter the weather plays an important part. You may plan a route, with every detail carefully thought out beforehand, and if that one factor, the weather, be unfavourable, you may find yourself taking a direction almost opposite to the one originally arranged. Large tracts of the eountry may be covered by snow, rivers may be unfordable, heithies turned into bogs, no grass may be found for the horses, clouds may hide the mountains, fogs cover the plateaux; all these obstacles, and others

* Papar read at the Royal Geographical Society, January 29, 1894. Map, p. 356. Figs. 4, 5, 8, and 9 are given by kind permission of the editor of the Glacialists; Magazine.

No. IV.-APRIL, 1894.] 
besides, may prevent a satisfactory survey of the parts through which your journey leads you. Hence it is not difficult to see why our knowledge of Iceland is still very fragmentary.

Furthermore, good pictorial representations of Iceland are not plentiful. Any one who examines the illustrated publications on Iceland will find them to contain either very few illustrations, or very incorrect ones, or reproductions of old time-honoured woodcuts, often copied secondhand, and mostly without acknowledgment. Under these circumstances, I think any real addition to our knowledge of Iceland will be welcome.

As for the physical features, there is, to my mind, no better mode at our disposal for taking down notes than photography. True, it cannot always be used, it is not even always unbiassed; but, wherever applicable, we have in it a means of recording an almost unlimited amount of detail with complete accuracy.

It has, therefore, been my endeavour to note down any observations: in Iceland, as far as possible, through the medium of the camera, and in spite of very adverse circumstances the result has been thoroughly satisfactory.

The journey which I undertook in company with Dr. Cahnheim, of Dresden, who had visited Iceland three years previously, was signalized by an almost unprecedented spell of bad weather. Of that vaunted clearness of atmosphere, so deceptive with regard to the estimation of distances, I saw nothing; on the contrary, I doubt whether an English summer landscape is often veiled in a bluish haze such as constantly enshrouded Icelandic scenery while we were there. Moreover, the temperature was truly arctic. From my companion's previous experience, and from all known accounts, we had prepared ourselves for a pleasant summer temperature, somewhat like that of the Scottish Highlands. In reality we found an everlasting north wind, opposing our progress northwards with unrelenting force for three weeks, chilling us to the bone, once actually compelling us to stop for three days in the wretched though hospitable farm of Stathir, on the Hrútafjörthur. On our way back the wind changed, and, though warmer, still with equal ferocity blew into our faces; once to such a degree that we could not put up our tent, and had no other choice but to urge on our poor horses for twentyone hours at a stretch.

On June 13, 1892, our steamer came in sight of the Vestmannaeyjar, and landed some passengers at Heimaey, the largest of this cluster of islets, the only one with a settlement; the others are inhabited by numberless sea-birds, and give pasture to sheep.

Although so late as June, the signs of spring had not appeared in Iceland when we arrived at Reykjavík (June 14). The country was in a deplorable state. There was hardly any grass out yet, and the prospects for a journey across country were very depressing. The sun, 
very powerful in fine weather, was hidden by heavy clouds which veiled even the lowest hills; of the mountain Esja nothing could be detected, and, although there was no night, neither was there any real bright day.

One particular feature struck me from the first day when we visited the nesting eider duck on the little isle of Engey, opposite Reykjavík-I mean the peculiar hillocks which are seen in Iceland wherever grass grows to any extent (Fig. 1). These mounds have a height of between 1 and 2 feet, and are usually covered by the best grass. Such parts are naturally selected as farmsteads; hence almost all the farms are surrounded by an area studded with low hillocks, over which walking is

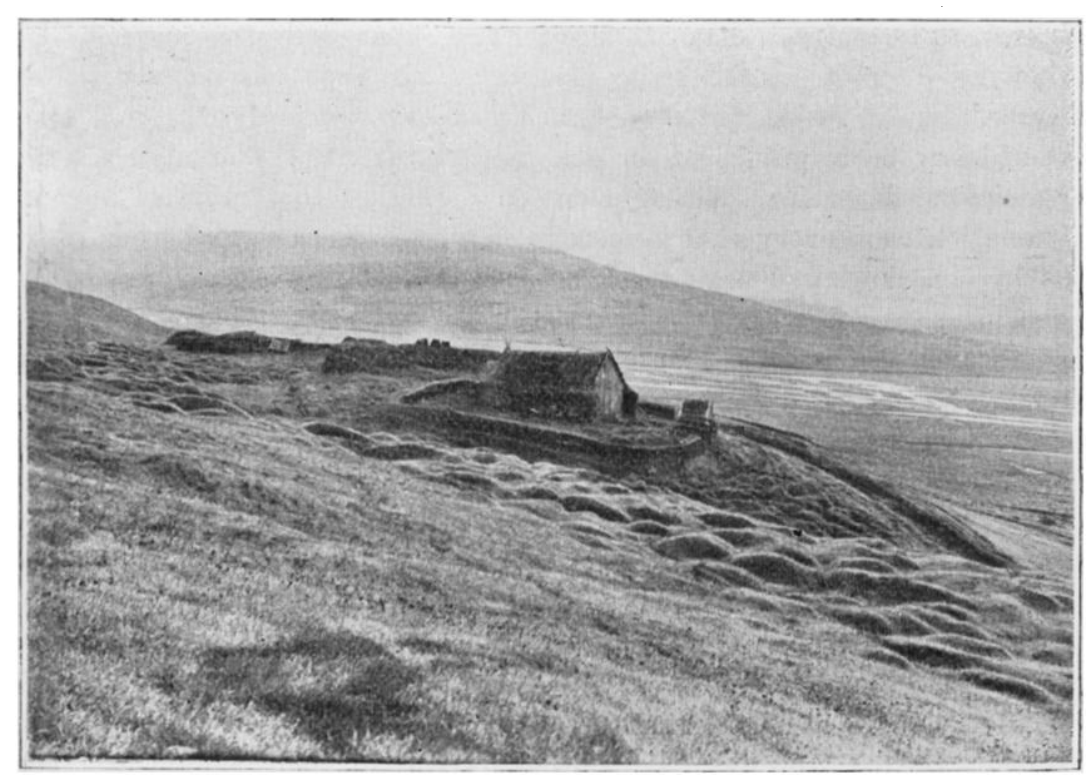

FIG. 1.-GRASS HILlocks AT SILFRASTATHIR ON THE PIJERATHSVATHN.

as fatiguing as riding is dangerous. The Icelanders, unpractical beyond conception, never dream of levelling these mounds; when ready, the grass can only be cut with a sickle.

In looking out for the solution of this peculiar phenomenon, an explanation soon suggested itself when we entered the Almannagjá. The snow, remaining longer than usual that year at the bottom of the rift, showed on its surface innumerable little conical hills of dark windblown sand, from half an inch to six inches in height. Their mode of origin by the melting of the snow in the heat of the sun is obvious. These sandcones on the snow are frequently met with in Iceland, and have been described by previous travellers. Their relationship to the ubiquitous lawn-covered mounds, however, has not been pointed out clearly as far 
as I could make out. After the formation of the sand-cones on the snow, vegetation takes hold of the loose soil, binds it together, and the form of the future lawn mound is perpetuated.

I think the cause of the great frequency of these sand-cones on the snow must be looked for in the low temperature of the air. The melting of the snow is due more to the direct impact of the solar rays than to conduction from the air around. It is for this reason that we do not find these sand-cones in our own latitudes. We find them, however, in the Alps, where the climate and average temperature resemble those of high latitudes, and where the force of direct solar radiation is strong in a thin, clear atmosphere.

The roads to Thingvellir and to the Geysirs are sufficiently well known to be omitted here. Suffice it to say that both traverse districts showing distinct glacial striæ (not the "signs or markings of snow water," but of ice-carried stones). My observations referring to glaciation have been published in the September (1893) number of the Glacialists' Magazine. I may mention here that the traces of ancient glaciation were everywhere apparent on our track, except where covered as by lava-flows and vegetation. I find it necessary to emphasize this, because recently it has been asserted in all seriousness that there never has been any glaciation in Iceland. Such a conclusion could not possibly be arrived at by any one who has either seen the country for himself or is acquainted with the literature of the subject. Glacial traces have been recorded almost over the whole extent of Iceland, and my own observations form a contribution which helps to complete the evidence already noted down so plentifully. It may be objected that these traces are only signs of "local" glaciers. But when we find "local" signs everywhere, we usually call them " general."

Of the Almannagjá, of the famous Althing, and of the lake of Thíngvellir, Lord Dufferin, who was completely fascinated, and Sir Richard Burton, who was disappointed, have given such graphic accounts, that I need not dwell at length on their appearance.

A very instructive exposure is given in the Almannagjá, showing the different layers of lava as they have flowed one above the other to form the large lava plain whose subsidence afterwards caused the two large rifts (Almannagjá and Hrafnajá) and the countless minor ones of the Althíng plain. The uppermost of these layers has been greatly demolished by weathering, and is only represented in its former height by a few large pinnacles. No artifical exposure could have been more perfect. The top of each layer is marked by very small columns; below these the columns are thicker, and at the base they are thicker still. This is not the rule with all lava-flows. Usually, the upper and lower parts consist of small columns, and the middle portion of thicker ones. Probably, the flows took place at short intervals, and so the earlier ones had not cooled down sufficiently to cause sudden chilling of those that succeeded. 
The scenic beauty of the Almannagjá is greatly enhanced by the upper and lower falls of the Exará. At the upper fall the river leaps into the rift, follows it for a short distance, and emerges at the lower part, to form a little further on the Thíngvallavatn, the biggest lake in Iceland. It is difficult to tear oneself away from this spot, interesting alike from a geological and from an historical point of view.

Our road leads us to the Geysirs. We were not fortunate enough to witness a spontaneous eruption. Although we waited three days, the Great Geysir kept quiet. The Strokkr was fed as a matter of course, and gave a beautiful explosion, about 100 feet high; rain and dark sky unhappily prevented a photographic record of the magnificent

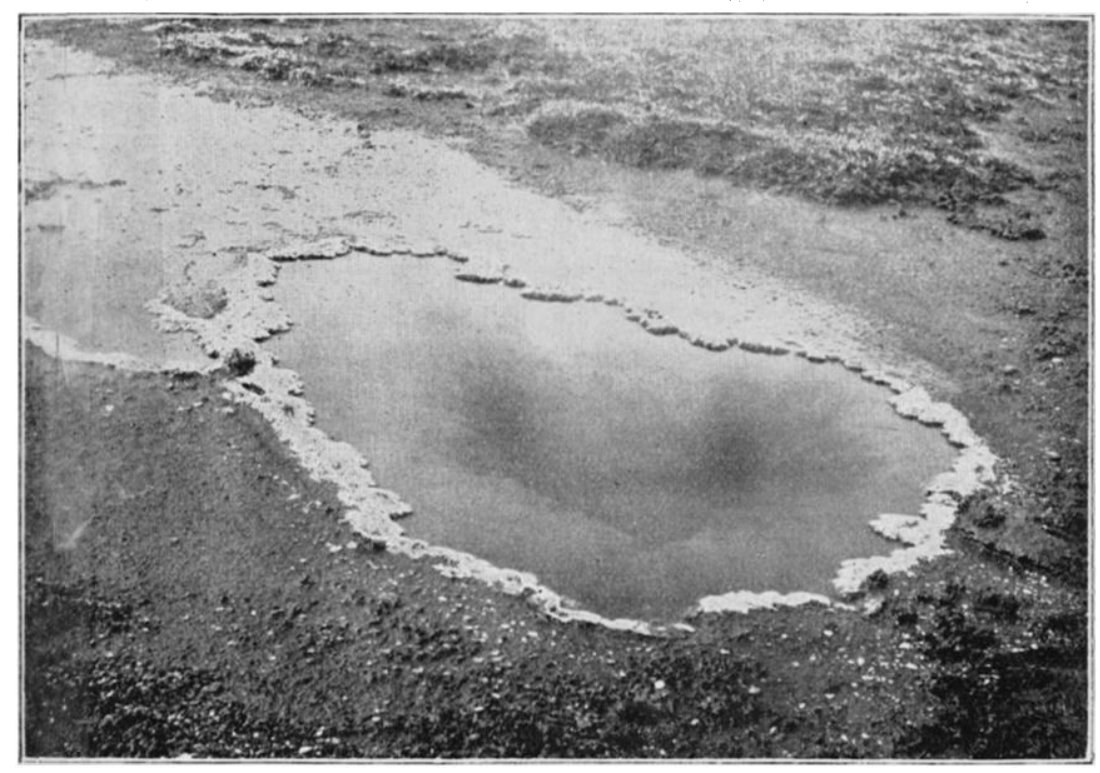

FIG. 2.- SINTER-FRINGED EOWL OF HOT SPRING IN THE GEYSIR GROCP.

display. In the Appendix the measurements and temperatures of the principal springs are given, so as to enable future observations to be compared with them.

The smell of sulphuretted hydrogen is very strong; it seems to be very unequally distributed amongst the different springs. "Blesi" is apparently free from $\mathrm{H}_{2} \mathrm{~S}$. When the thermometer was taken out of Strokkr, the metal cover was completeìy blackened, while in the tube of the Great Geysir it had remained untarnished. It was found that the temperature at 22 meters depth in the tube of the Great Geysir was sufficient to fuse completely the solder with which I had closed the ring at the upper end of the thermometer. Happily, it had been securely 
fastened by several loops, or else it would have been lost. It is impossible to describe the exquisite beauty of some of these springs with their marvellous transparent blue-greenish water; only a faint idea of them can be given by a photograph (Figs. 2 and 3 ).

From the Geysir it is only a couple of hours' ride to the Gullfoss, probably the fullest of Icelandic waterfalls. In a broad cascade the opaque waters of the Hvítá slide down between narrowing walls of basalt until they reach a bend where they suddenly leap into a chasm 80 feet deep.

The state of the country made progress directly north from Haukadalr impossible, so we had to return to Thíngvellir. In fine weather

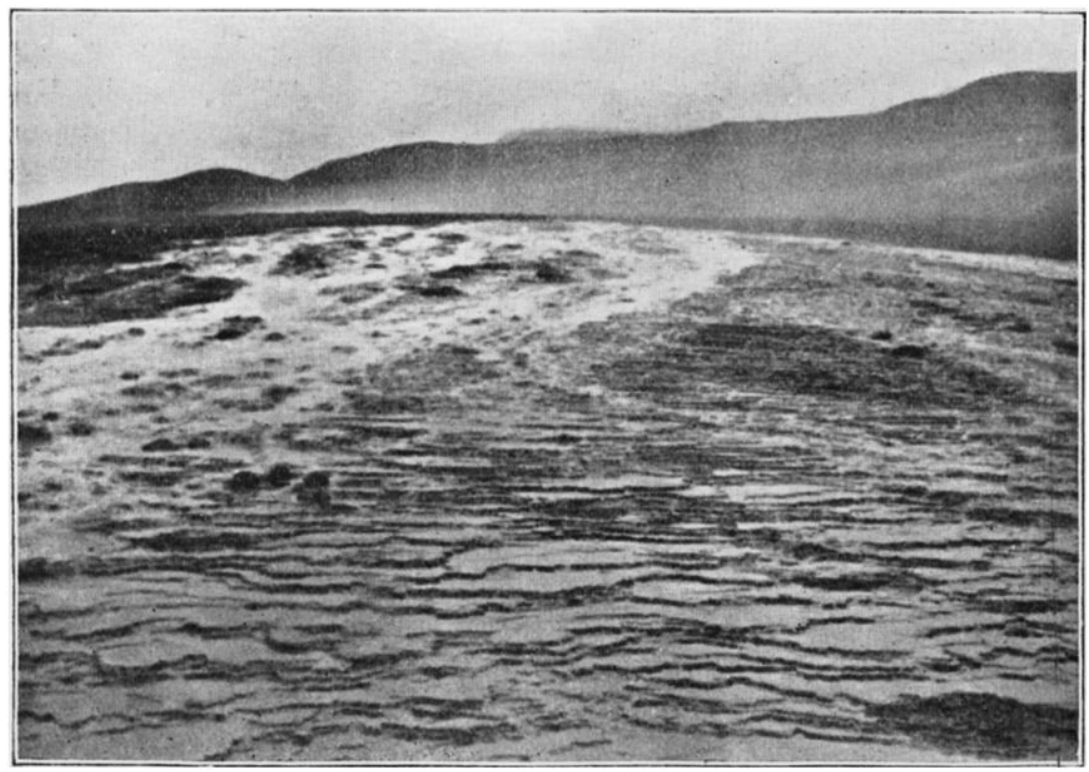

Fig. 3.-SINTER TERRACES FORMED BY THE OVERFLOW OF BLESI, ClOSE TO THE GREAT GEYSIR. THE SINTER IS PALE PINK IN COLOUR.

there can be scarcely a more delightful sensation than that of riding through scenery such as this, so well known to most Icelandic travellers. The dwarf birch has a fragrance which I have never found anywhere else; legions of large grey moths flit about in the balmy air; the sun sends down his warming rays; and in the distance the snowy head of Hekla and the Southern Jöklar stand out from the blue sky. Alas! this delicious picture soon vanished, never to return for the rest of our journey.

The typical Icelandic "forest," skogar, is formed by fragrant dwarf birches, shrubs of about 3 to 4 feet high. Equally peculiar is an ordinary Icelandic road. It is nothing but a rut cut by the feet of the 
countless generations of ponies which have been driven along in this direction. These ruts are deep, usually very narrow, and if the luckless rider is endowed with fairly long legs, the riding resembles more a performance on a bicycle than anything else. Often the ruts branch off sideways, and with a jerk the pony may bolt into the branch, when it is difficult to keep in the saddle.

From Thíngvellir we take the track called Hofmannaflötr. A glance backwards shows the lake in the distance. At Brunnar, a deserted spot, we see the ice-covered Armannsfell, and to the right we have now the beautiful volcano Skjaldbreith, about which more presently. On we speed, the north wind (truly arctic) well-nigh blocks our progress through the Kaldidalur, a high pass between the vast inland glaciers. As we ascend, the temperature gradually falls, the rain turns into sleet, the sleet into needles of ice, and the storm rages so furiously that our horses can hardly make any headway at all over the vast expanse of sloppy snow, in to which they sink often over their knees. The thermometer shows $+0.5^{\circ} \mathrm{C} .\left(33^{\circ} \mathrm{Fahr}\right.$.). After five hours of hardest experience, we emerge from the clouds and descend to the silvery band of the Northern Hvítá at our feet, which we reach after another hour; then through the icy waters of the river and over a desolate lava-field, until at last the hospitable though expensive farm Kalmanstúnga gives us shelter. So desolate was the route traversed that day, that the only signs of life we found in the Kaldidalr were, as my companion expressed it, one bird and one dead moth.

I mentioned Skjaldbreith before. This beautiful volcano, only about 2500 feet high, covers an area of nearly 30 square miles. It is of perfect regularity, a very obtuse cone, the inclination varying between $8^{\circ}$ and $9^{\circ}$ on the different sides, resembling in this respect the Hawaian volcanoes. So regular is its outline that it would seem to be easy enough to ride to the top, provided there are no rents of any great width to cross. The top is, however, ice-capped all the year round, and a ride up would probably give no information. Skjaldbreith gives us the key to a number of snowy cupolas in this district. First amongst them for its exquisite regularity is the ice-dome of Ok. Hidden from our eyes by fog and clouds were those two snowy cupolas which Messrs. Preyer and Zirkel describe so graphically (in 1860), the snowy breasts of a young giantess turned into stune, according to an Icelandic legend. We find them again as "Sheba's breasts" in Rider Haggard's novel, 'King Solomon's Mines.' There is, further, the western termination of the Lángjökull, the Geitlandsjökull, showing the same beautiful curve; and also the impressive Eyríksjökull (Fig. 4). (I have pointed out in the notes on Glaciation how this profile of the Eyríksjökull speaks in favour of a south-north direction of an ancient glacier covering the Eyríksjökull completely). This massive mountain, covering an area of over 30 square miles, stands like an outpost by the large Lángjökull. It is an old volcano, and is 
probably responsible for the lava-field which stretches to the southwest, skirting the Strútr, on the southern slope of which Kalmanstúnga is situated. The ridge above the farm is strewn with a stratified ash. The lava, like that of Thíngvellir, is mostly ropy. The surface is often covered with a green or brownish glaze of tachylitic nature. Often there are hollow spaces underneath the surface, and then the hoof of the horse striking it produces a peculiar musical sound.

These lava-fields are always very trying to the horses, and often exceedingly dangerous. Their general appearance varies much, but it always reminded me of the sea. Sometimes they are quite flat, with or without small ripples on the surface; sometimes you see beautiful undulations of wave crests and hollows, like an ocean swell; sometimes you find a regular choppy sea, and occasionally the forms of pack-ice left in a mad chaotic struggle, and sticking up when consolidation overtook these destructive streams.

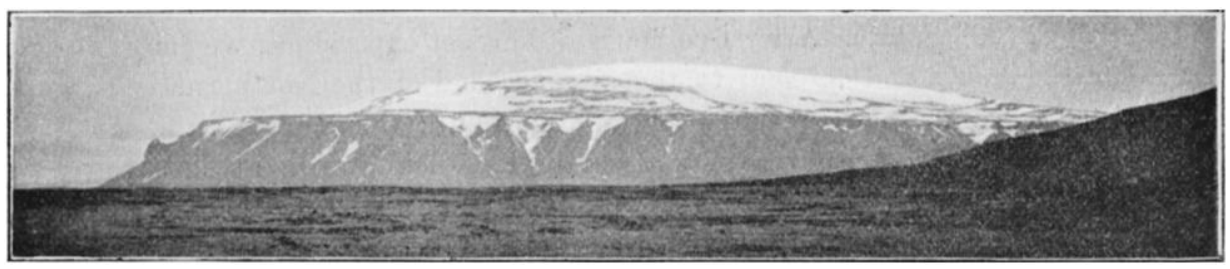

FIG. 4.-VIEW OF EYRíksJöKULL FROM WEST, TAKEN AT A DISTANCE OF 9 MILES.

The lava north of Kalmanstúnga must have been of great viscosity, as shown by the ropy surface and its curves. The large wave mounts are usually cracked, and resemble the broken crust of a pie. The fissures, caused by the cooling of the lava, form one of the greatest obstacles to the progress of the horses; often they are treacherously hidden by a covering of grey moss, of almost the same colour as the lava itself. They show generally a very well-marked columnar structure, perpendicular to the surface of the flow.

A smail stone cairn marks the entrance to Surtshellir,* a roundish opening of about 50 feet in diameter, filled very irregularly with big lava blocks, and covered with large masses of snow, reaching deep down into the cave itself. The description of Surtshellir has been given so well by Olafsen and Povelsen, by Henderson and by Preyer and Zirkel, that I shall confine myself to a few remarks concerning the most distant parts. After twice emerging into daylight from exceedingly fatiguing scrambles for more than 4000 feet underground, over big lava blocks piled up in chaotic disorder, we plunged for the third time down on the steep snow incline into the pitch-dark hole before us. Soon the snow

* Surtshellir : Surtr, a troll or giant, means "black" = schwarz (German); swarthy, in English; hellir = hollow = höhle (German); кồ os, in Greek ; coelum, in Latin. 
ceased, and after a few paces we came on solid ice, flooded with several inches of water, through which we had to wade. The ground was exceedingly slippery; handicapped and laden as we were, we could hardly keep our balance, candles in hand, especially when, after a few feet of rise, the ice-coated ground began to slide downwards. But only a few steps more, and we were rewarded by one of the most enchanting sights it had ever been my good fortune to behold. Out of the floor, uneven, slippery, and more and more slanting, there seemed to rise ahead of us a number of fantastic forms, standing out pale in the uncertain light from the ice floor. On approaching with the candles, we recognized in these pale mushroom-like forms the most gorgeous ice stalagmites, of varying sizes and shapes, scattered all over the slanting floor of the cave, from the densest white to a pale blue of ghost-like transparency. Some were solitary, others formed a cluster; some, in the style of a Gothic spire, were surrounded by a tier of secondary spires, while others, almost mathematically perfect in shape, formed isolated transparent paraboloids.

On the north-western wall of the cave (the main direction of the whole cavern runs from north-north-east to south-south-west) there was a magnificent curtain of long ice-stalactites, forming a colonnade and partitioning off a corridor wide enough to allow us to walk along with a lighted candle. Where stalactites and stalagmites had met, somewhere near the middle of this colonnade, they resembled the face of an organ. (Photographs were taken under almost insuperable difficulties by magnesium flash, but form almost the best of the whole collection.) Add to this the thousandfold sparkling and glittering from those parts of wall and roof which were not draped by graceful icicles, and you will not wonder that we felt completely dazed, as if transported into the midst of a fairy tale of our childhood. (The brilliant sparkling effect, particularly impressive by flash-light, was produced by peculiar forms of ice-crystals which have been described separately in a paper placed before the Royal Society.) With difficulty we tore ourselves away from this enchanted spot. When, at last, we reached the glimmer of daylight, the exit of the cave gave a charming effect. The temperature in the cave and outside on our way back to Kalmanstúnga was $+0.5^{\circ} \mathrm{C}$. $\left(33^{\circ} \mathrm{Fahr}\right.$.).

Four weeks later the adverse state of the weather and of the country brought us once more near the caves. On a ride so severe and fatiguing that it stood out as the worst from all our other severe experience, we came from the north in feverish haste to catch our steamer at Reykjavík. So wild was the storm when we reached the Fiskivötn (fish lakes), that no tent could be erected. Before us rose the massive Eyríksjökull, its snowy head covered by heavy clouds, which the mad south-westerly storm tore into long streamers. In lurid tints appeared the tongues of the descending glacier, the storm raging against us, we racing on at full speed; before us, in majestic repose, the enormous mountain. At a 
distance of ten miles from the mountain a photograph was taken, while I had to sit on the camera to steady it against the violence of the storm (8 p.m.).

After five hours' further ride, the entrance to Surtshellir was reached, and a descent was made, this time in quest of the coins which had been deposited on a stone block in the remotest recess by Olafsen and Povelsen in 1753, and by Henderson in 1815. I knew of them through the allusion of Preyer and Zirkel, who had failed to find them in 1860.* Fatigued in the extreme, after a nineteen hours' ride, we succeeded at last in finding the tin plate with the coins on a piece of wooden board, on the top of a big block of lava. The water dropping occasionally from the ceiling had cemented some of the coins with a sort of sinter to the plate. Some coins had old seals hardly recognizable, others were more recently placed there. I took two of the oldest coins, both with seals (exhibited). The one is probably from Henderson, to judge from the seal which represented a sitting figure of Christ and some Hebrew lettering; the other is of the year 1668, probably one of the Olafsen coins of 1753 . Although I exchanged these coins for their equivalent in modern kroner, I shall not feel satisfied until I have restored them to their old restingplace in Iceland, in the course of a year or two.

And now back to our journey.

From Kalmanstúnga we went to Reykholt, famous as the seat of Iceland's greatest son, Snorri Sturluson, who was murdered there in 1241 by his own son-in-law. Well preserved up to this day is the Snorralaug, or Snorris' bath, a circular basin about 12 feet in diameter, 4 feet deep, and lined with stones. Four stone steps lead into the bath, which is filled with warm water from one of the hot springs some 200 yards distant by a primitive stone channel. An overflow keeps the depth about $2 \frac{1}{2}$ feet. On the morning of June 30 , the temperature of the water was $46.5^{\circ} \mathrm{C}$. If the temperature is required lower, the supply is stopped temporarily, and the water allowed to cool to the desired aegree. There are several springs close together, about 200 yards east of the bath, which is supplied by the principal spring. This latter boils up in a continuous jet 1 to 2 feet high. The thermometer would not sink beyond 1 foot below the surface, and showed $98 \cdot 5^{\circ} \mathrm{C}$. Close by is a small boiling jet, quite shallow $\left(89^{\circ} \mathrm{C}\right.$.), and not very far another spring, with a large and shallow circular mud bowl. It does not rise; the temperature was $98^{\circ} \mathrm{C}$. All these springs have a strong smell of sulphuretted hydrogen.

The next day we continued our journey down the Reykholtsdalrt, which is very rich in hot springs, as indicated by its name. The most

* " On we went, hoping to find the coins which Henderson deposited in 1815 on a small stone heap. After a short scramble over sloppy and gently sloping ground, we actually found the stone pyramid, but not the slightest trace could be detected of coins or seals" (Preyer and Zirkel, 'Reise nach Island,' p. 104). 
curious of these are the two Geysirs in the river itself. In the midst of the river-bed a rock of siliceous sinter rises about 18 feet long, 6 feet wide, and 5 to 6 feet high; at each end a hot spring spouts. The southernmost is the smaller, both in volume and height; it only springs up to 6 inches. The thermometer descended to a depth of 2 meters, and showed $100 \cdot 5^{\circ} \mathrm{C}$.

The other spring, on the northern end of the sinter block, rises 2 to 3 feet high, but could only be measured 1 foot below the orifice $\left(99^{\circ} \mathrm{C}\right.$.), where the cap of the thermometer was caught and had to be left behind.

On turning northwards we had to search for a ford in the Northern Hvítá. Through all our journey the rivers were in a very plethoric condition, while our horses were the opposite; crossing a broad, deep river of opaque whitish water, with the banks constantly changing, was therefore a serious undertaking. Our guides first rode to a flat island in the river; there they drove two of the spare horses into the stream. One of them found a ford, the other had to fight hard against the stream by swimming. The ford having been found, the caravan was divided into three parts ; the horses were tied together, the tail of one to the head of the next, in batches of six or seven, and then led by one of the men across the stream. This ensures their following in the same track, an important point when wetting the luggage had to be avoided.

The Icelandic horses are as good natured as they are invaluable. How they can go on carrying the primitive pack boxes on the still more primitive pack-saddle is a mystery to me. They will stand anything, do almost anything, but they will avoid going over a bridge if they possibly can. Once we had to cross a deep cutting near a farm; a few planks covered with soil were placed across. Some of our horses were driven to this bridge, and hesitated until urged on, when two of them at last rushed on to it abreast. The boxes sticking out on both sides clashed together, and the impetus was such that both animals were thrown from the bridge, one on each side, and disappeared below. Strange to say, no lasting injury followed this peculiar display of equine gymnastics, except a few scratches on horses and boxes. Henceforth our horses were allowed to have their own way as far as possible.

North of the Hvítá the basalt is rich in amygdules and zeolites. The basalt of the Grjótháls is smoothed by glaciation, while the pyramidal Baula is split up into very regular columns. We rested at Hvammur. The desolate Holtavörthuheithi was veiled from our view by fogs and storm ; descending, we saw the first wild swans, a white fox, and ptarmigans. In pouring rain we passed a fine vertical basaltic dyke denuded by a brook which had breached it; the hexagonal ends formed a design of geometrical regularity. Two hours later we scaled with an effort the incline on which stand the farm and "post-office" of Stathir, our destination for that day. For two days the storms kept us prisoners in Stathir. When at last we proceeded we found a good amount of drift- 
wood thrown on the shore of the Hrútafjörthur. After a visit to the amiable merchant and his wife at Bortheyri, we went north-east, vi $\hat{a}$ Melstathir, past the Midhóp, and crossed the remarkable hills near Hnausar, the Vainsdalsholar (Fig. 5) which I have described in the Glacialists' Magazine. In this part we found the only yellow poppies (Papaver nudicaule) we saw during our journey. Very few flowers were seen altogether in that year most abundant were the lovely cushions of Silene acaulis, from pale mauve to pink and almost crimson; Dryas octopetala; Caltha palustris of gigantic size; Geranium montana; but not a single gentian in blossom.

Turning to south-east, the cone of Reykjanybba rose before us like a volcano in outline. The farm Reykir is situated at its foot on the north side; its north-east flank has a fine example of a glacial "boss," reaching down almost to the level of the long narrow Svinavatn. At Reykir there is a hot spring, mounted on an artificial basin of stone, oval in shape, 10 feet long, 7 feet wide, 1 to 2 feet deep. Temperature

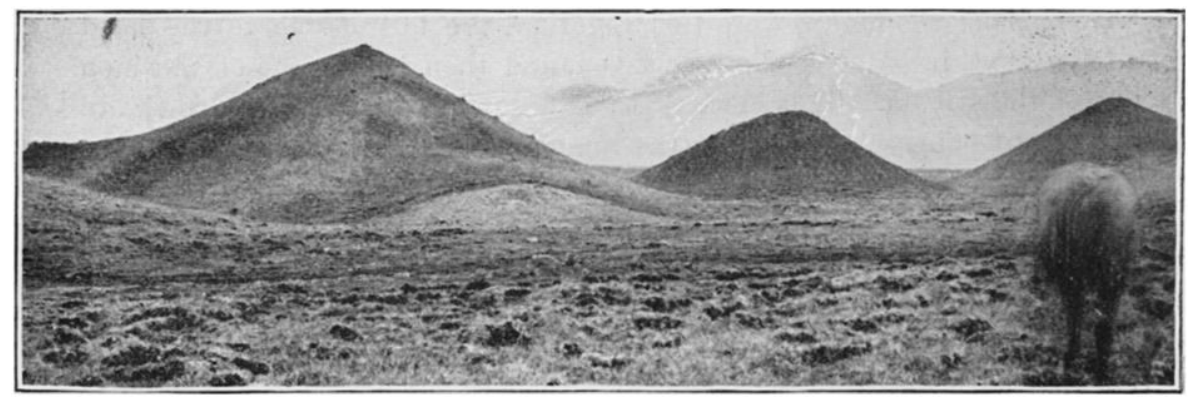

FIG. 5.-GLACIAL DRIFT Hills NeAR hNALSAR, CALled vatNSDalsholar.

$53.5^{\circ} \mathrm{C}$. At the lake we met for the first time with little flies, not very troublesome, nor very numerous.

The rivers Svartá and Blandá, both swift and deep, had to be crossed; they have the characteristic appearance of an Icelandic river in an upland valley. In the farm of Bolstatharhlith we found one of those beds peculiar to Iceland, which can be made longer or shorter to suit the anatomy of everybody. When not in use they are telescoped together like a table, thus economizing space. The sagacity of Icelandic road-makers is shown by a "road" leading straight over a very fine hemispherical glacial mound near Vithimyri, where it would have been much easier to circumvent it horizontally. When coming to the river Herathsvatn we found fording impossible, and had to take the "ferry." This title is in Iceland applied to a leaky boat that can be rowed across a river by one man while another bales out the water as fast as he can. When the luggage and the travellers have reached the other side, the horses are driven into the stream and have to swim across, no easy task 
in the swift current. We nearly lost one of our best riding-horses, which had to be rescued by the timely help of the boat. While we were waiting on the shore for the horses, we saw close to us three seals rising repeatedly out of the river, first going up and then down stream. As soon as the horses had reached the shore they threw themselves on the ground, as usual, and rolled their backs in the sand. What objects of art they looked may be readily imagined when I add that their winter coats, nearly three inches long, had come off in patches only, leaving underneath a short summer coat. From my own experience l never saw the horses "groomed" or "cleaned" in any other way than that just described.

In Silfrastathir a very fine hand quorn for grinding corn attracted my attention; it was, however, too heavy to be brought away. Entering the Exnadalur, we came to some of the most picturesque mountain scenery in Iceland; a fine valley opens on the south side. Backasel is a typical farm, the interior showing the arrangement of beds, like berths in a ship. To procure more privacy, a cord is put up and a curtain hung in front of the berth which is occupied by two or more people. All the inhabitants of the farm sleep in the same room for the sake of warmth.

At the farm Steinstathir, an ancient wooden hand-mangle was procured; these "trafakefli" have not been in use for the last 200 years. When entering the Eyjafjörthur we rode over endless roches moutonnées, until we reached Akureyri. Akureyri prides itself more on possessing the biggest trees of the island than on anything else. It is a flourishing settlement of about 500 inhabitants in the picturesque Eyjafjörthur. The trees are a few healthy-looking but small specimens of Sorbus aucuparia (rowan tree).

Leaving Akureyri, we crossed the fjord on horseback, the ebb being favourable. It is an experience of its own to ford for more than half an hour that long inlet of the Polar Sea. The Eyjafjarthará forms a very fine alluvial delta, the channels and banks of which are continued below the surface of the water for a certain distance into the fjord. When riding across the fjord the horse has to take these channels and banks alternately, being often only knee-deep in the water, often up to the shoulders. Where the water is shallow, he splashes with legs and knees, and progress, if hardly visible in the vast expanse of the fjord, is at least audible. But as soon as any of the channels are reached, the horse sinks down to the shoulders, the splashing of his legs ceases, not a sound is heard, and the deadly silence has something strangely uncanny about it.

The steep incline of the eastern shore was afterwards scaled-a height of over 2000 feet-and revealed a magnificent view of the delta and the fjord (Fig. 6). On our descent through the Vathlaheithi we found ptarmigans plentiful. Attracted by the rattling noise of the 


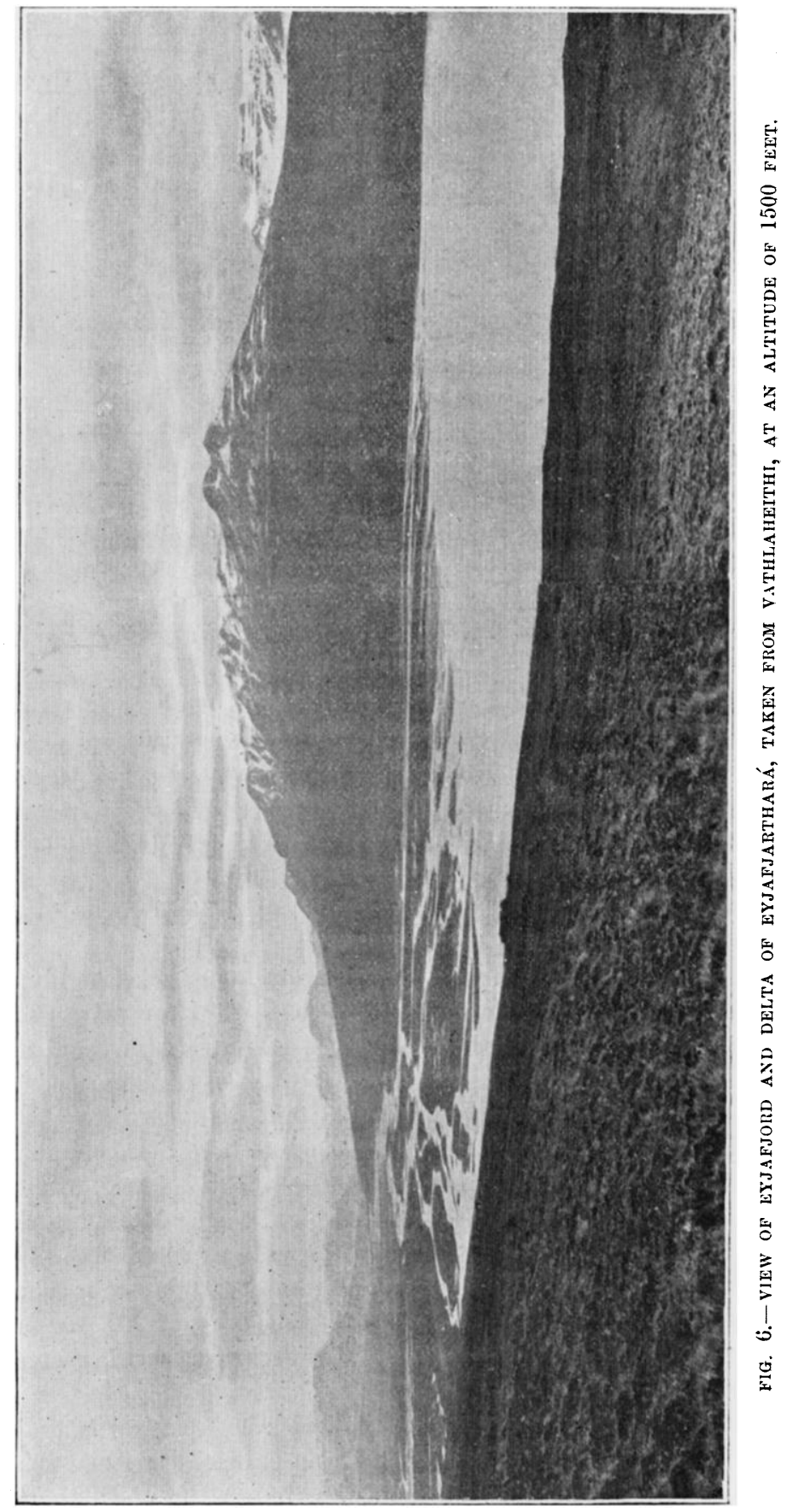

This content downloaded from 155.69.24.171 on Sun, 19 Jun 2016 18:17:27 UTC All use subject to http://about.jstor.org/terms 
mother, I repeatedly noticed the young birds almost under the hoofs of our horses. Not able to fly yet, they were caught easily with our hands, but were soon restored to the caresses of their anxious parents.

The river Fnjoská is not broad, but swift and dangerous, owing to the large boulders it carries along. The rate at which some of these streams flow is often astonishing. On our way homewards I was struck by the furious pace at which the swollen Hèrathsvatn raced past Silfrastathir. I measured the velocity in different parts, and found it varying from 3 to 5 meters per second. This was probably exceptional, and due to the great amount of rain during the preceding fortnight.

Beyond Háls we saw a gigantic striated boulder. Evidences of glacial action abound in this part, except where recent lava streams have obliterated them. This has been partly the case at Ljosavatn, although the hill-slope towards the east shows very fine perched rocks standing out against the sky. Half an hour east from Ljósavatn the impressive Gothafoss is formed by the leap which the Skjálfandafljót takes into a broad rent in the post-glacial lava. Here the greater number of bridges of the island are crowded into a small area; the roads too are partly very good, almost fit for a wheeled vehicle. At a very poor farm we were consulted medically, and while my companion attended to the patient I took a view of the picturesque exterior of the building.

When riding past the churchyard of Grenjatharstathir we saw three basaltic columns lying on tombs. All three were very perfectly regular six-sided prisms, and were placed in a west-east direction on the grass. One stone had runic inscriptions on the three upper sides-the only runes we saw in Iceland; the second stone showed a much weathered inscription on the uppermost side only, in Latin characters; the third had no recognizable inscription at all. When the wooden handle of my hammer touched one of the columns by accident, a ringing musical sound was produced, varying in height on the different faces of the same column.

Stone I.-Length, $129 \mathrm{~cm}$.; greatest diameter, $19 \mathrm{~cm}$. The three upper. surfaces have runes, which we photographed. When struck with the knuckle of the middle finger an almost singing sound is produced. On the largest southern and northern (opposite) faces that note was as determined with the little tuning-fork which I always carry with me; the upper and the adjoining northern face give a note a third higher,

Stone II.-Length, $150 \mathrm{~cm}$; greatest diameter, $21 \mathrm{~cm}$. When struck, the upper and adjoining southern faces emit the note while the upper northern and the opposite face ring a clear

The inscription on the upper surface is badly weathered; a photograph. would not have shown anything, and a rubbing was therefore taken with 
a bit of cloth coloured by some iron-stained amygdules. With great difficulty I deciphered the following:-

" HIER + HVIILER + I + DROTTNI + THORGRIIMVR + HE . . 'SSON."

("Hier hviler i drottni thorgrimur he .. 'sson.")

(i.e. "Here rests in the Lord Thorgrimur $\mathrm{He}$. . 'sson.")

Stone III.-Length, $133 \mathrm{~cm}$; ; greatest diameter, $19 \mathrm{~cm}$. No inscription. When struck, the upper northern face emits the note the upper southern face while the narrow top (face between the others) gives a note between $c$ and $b$, full of interference jerks.

(Mr. S. B. Gould gives on p. 194 of his book, 'Iceland: its Scenes and Sagas,' a correct rendering of the runes of Stone I., taken by a " rubbing with a German sausage," as he amusingly says. For the copying and translation of the inscription on Stone II., however, we can hardly make that sausage responsible; it is thus given: "Hjer hvilir Idrottni Thurur . . . ." “Here sleeps Idrottni Th—_'s daughter." Idrottni is not a name for a girl, but it means in Icelandic "in the Lord," and the inscription shows not "Thurur . . ." but " Thorgrimur $\mathrm{He}$.. 'sson.")

A few hours north of Grenjatharstathir we see the steam rising in the distance, denoting the spot where the Uxahver-or Northern Geysirs carry on a soməwhat sluggish existence. There are three springs in all, the largest resembling the Great Geysir. Its circular bowl consists of siliceous sinter, and has a diameter of 30 feet; it does not spout often. As we were riding away we noticed the water rising in the centre for a moment, about 2 feet high only. The second spring is the most active; out of a bowl, 3 meters in diameter, it throws every five to ten minutes a jet of water to a small height, sometimes up to 4 meters, $3 \frac{1}{2}$ meters below the surface of the water the thermometer registered a temperature of $103^{\circ} \mathrm{C}$. The third spring is comparatively insignificant, only a short distance to the south-east.

A small orchard has been placed close to the springs, and sheltered on the far side by a low turf wall; in the warm damp air potatoes thrive merrily.

The end of that day's journey brought us to Ásbýrgi, a rift, if not so well known as the Almannagjá, at least equally remarkable. From its parent rock a huge triangular wedge is separated by a perfectly flat depression, half a mile wide, $\mathrm{V}$-shaped, each side of the $\mathrm{V}$ about a mile and a half in length. The rock rises perpendicularly to more than 300 feet, and is formed of many layers of a coarse doleritic lava, imitating with its vaulted flows the walls of a mediæval castle, with arches and windows. The rift is well sheltered from storms; we found near the apex of the $\mathbf{V}$ quite a respectable little birch forest, with trees of five to six yards in height-the tallest forest trees in the island. A good deal of snow and a dried-up pond at the end took the place of the "lake" which our guide had led us to expect. 
Ásbýrgi was our most northern point reached on this journey. A day's ride brought us to the eastern limit, to that finest of all Icelandic and European waterfalls, the Dettifoss. The access to the fall, marked from afar by a white steam-cloud, leads over uneven, barren territory of pre- and post-glacial lava. With one tremendous bound the Jökulsa leaps into the largest of those volcanic rents which in this part of Iceland have a north and south direction. The rift is about 300 feet deep and 500 feet wide, and shows in its perpendicular walls four distinct layers of lava, with exquisite columnar structure. When Gunnlangson drew up his great map of Iceland in 1844, the Dettifoss was not known; on the later maps its position is variously given. When we were there, the white

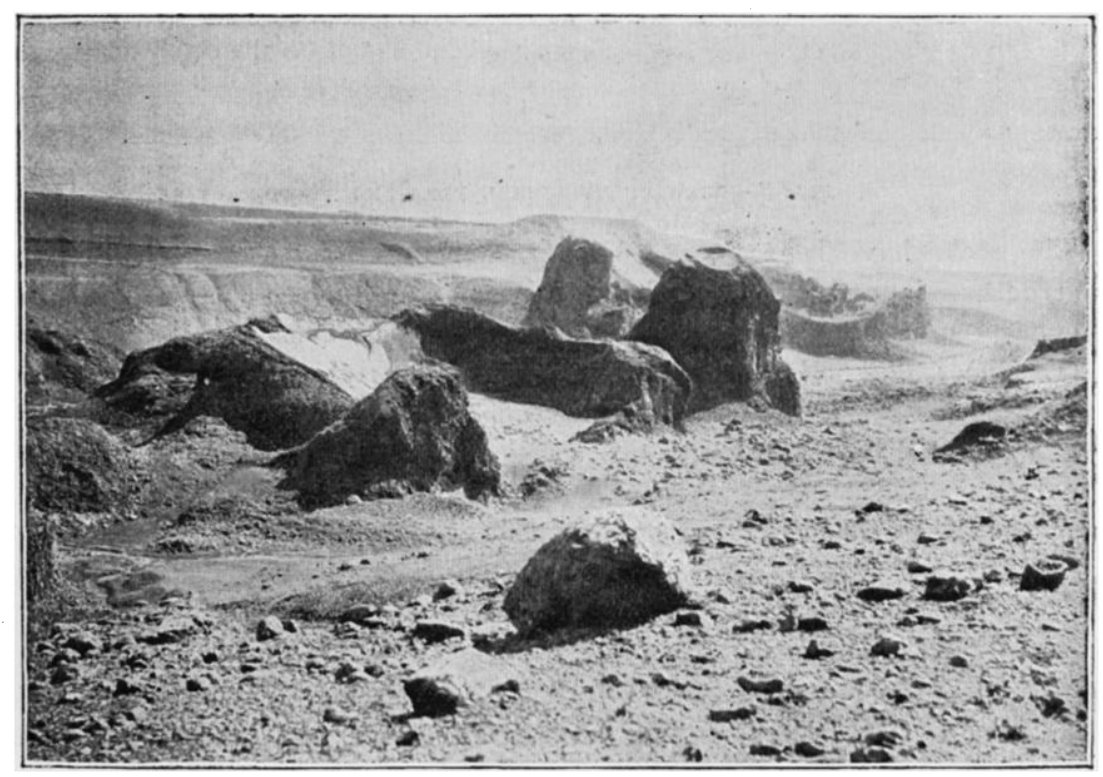

FIG. 7.- SOME CRATERS OF THE HLJÓTHAKLETTAR GROU1.

cone of Herthubreith, at a distance of about 50 miles, and the mountain Eilífr became visible for a short time, enabling us to take the following compass bearings: Herthubreith, $215^{\circ}$ magn.; Eilífr, $297^{\circ}$ magn. Allowing $37^{\circ}$ for westerly declination, this would give almost exactly the spot on Gunnlangson's map where the dotted boundary-line between the northern and southern Thíngeyjarsýsla cuts the Jökulsá.

Of intense interest between Ásbýrgi and the Dettifoss are the Hljóthaklettar (rocks of sound or echo). Thoroddsen * gives the following brief description (Fig. 7):-

"The so-called Hljóthaklettar are a series of steep basaltic peaks

* “Eine Lavawüste im Inners Islands,” Petermann's Mitth., 1885, ix. p. 331.

No. IV.-APRIL, 1894.] 
150 to 200 feet high, of the most curious forms. The basalt of these rocks is split up into small columns variously arranged, often in a semicircle round small openings. The cause of this irregular formation is erosion, which has washed out the palagonite breccia, while basaltic dykes remained; here and there some breccia is still found enclosed in hollows in the rock."

A closer study of some of the photographs of these remarkable rocks shows that this explanation is erroneous, or at least incomplete.

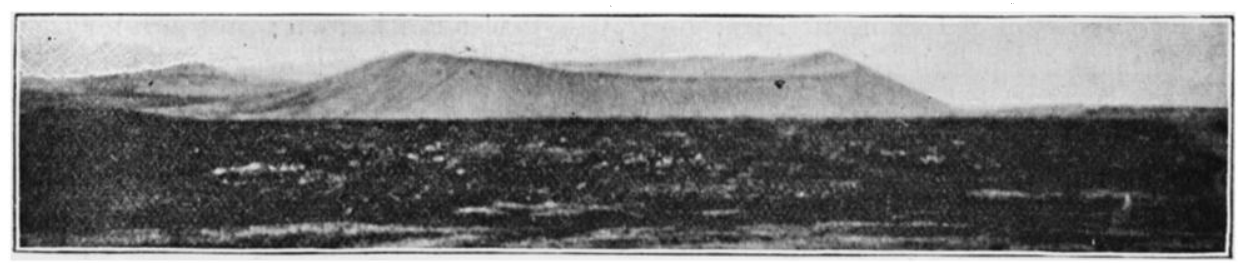

FIG. 8.-VIEW OF HVERFJALL FROM NORTH-WEST.

The rocks have been formed by a rather liquid lava. The columnar structure is certainly the finest $I$ have erer seen, and is found in every one of the rocks where they show an exposure (denuded by erosion). The hollows, however, are so regularly spherical, and in one instance so large-about 100 yards across-that they cannot possibly be explained by the filling up of a space round a nucleus of palagonite

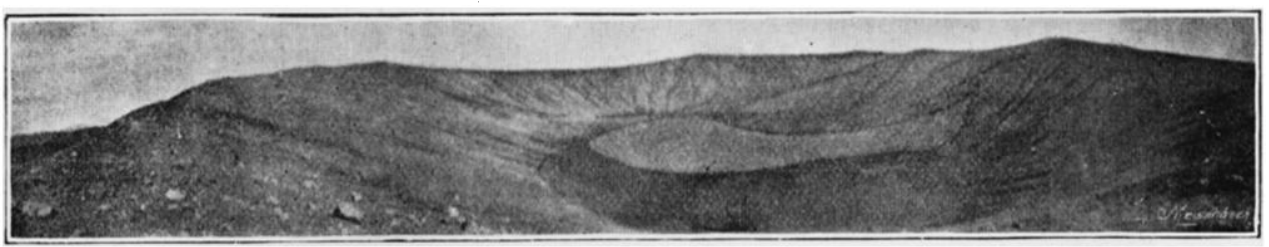

Fig. 9.-INTERIor OF THE CRATER HVERfJall, With MOUND AND RIDGE IN CENTRAL PLAIN.

breccia. These craters are evidently the same formation for which Dutton * proposed the name of "caldera." They are produced by lava basins which, having been tapped and drained at lower levels, have formed semicircular hollows by the aspiration of the stiffening but still fluid lava. The various sizes of these drainage hollows and channels can be seen in the different photographs taken. The columns are smallest near and perpendicular to the surface of the hollows, proving thereby that cooling began from these hollows, which were probably open spaces and had time to cool before a subsequent filling up with breccia took place. Afterwards the breccia has been weathered out, while the harder

\footnotetext{
* ‘Hawaian Volcanoes,' p. 105.
} 
basalt has remained. That the basalt has not escaped erosion altogether is shown by various big uprightrocks, and also by the circular crater or. " caldera," of which the larger half is preserved, while about two-fifths have disappeared. It would be difficult to say how far the breaking down of these hard masses may have been hastened by earthquakes or similar violent shocks.

A few remarks only about the Mývatn. The beautiful crater Hverfjall (Figs. 8 and 9) and the unique phenomenon presented by its interior have been described by me in extenso in the November number of the Glacialists' Magazine. The steaming sulphur mountains, the mud geysirs, the desert, have been well described by previous travellers. The Hrafutinnuhryggur formed the subject of a special excursion, and enabled us to collect exquisite specimens of Obsidian.

From Mývatn.we returned to Akureyri, expected by more than fifty people seeking medical and surgical advice, some of whom had come a long distance. Then followed our hurried ride across the country in order to catch our steamer at Reykjavik. Of the last 66 hours, we spent 44 in the saddle; but we had the satisfaction of arriving at Reykjavík just in time.

\section{APPENDIX.}

Geysirs. June 20, 1892, 1 P.M.; Barom. 29.575" Engl.

1. Great Geysir. Bowl (crater) oval, obliquely elliptical ; diameter, west-north-west to east-north-east $=15.5$ meters $;$ north to south $=17 \cdot 5$. meters. Temperature at 22 meters depth., $123 \cdot 5^{\circ} \mathrm{C}$.

2. Blesi. Temperature 9 meters below surface, same as near surface $=94^{\circ} \mathrm{C}$. ; surface level with ground, overflowing.

3. Spring close to Blesi. Surface of water 2 meters below opening; thermometer reaches 6.5 meters, deep in water, and registers $101.5^{\circ} \mathrm{C}$.

4. Steaming mud spring close to Blesi. Thermometer enters only 4 inches, and shows $95^{\circ} \mathrm{C}$.

5. Strokkr. Surface of water 3 meters below opening; temperature in 10.5 meters of water, $108^{\circ} \mathrm{C}$.

After the reading of the paper, the following discussion took place :-

Sir Archibald Geikie: At this late hour, and after such a pleasing excursion through Iceland, little room is left for comment or criticism. The photographs have given us a vivid picture of Icelandic scenery, and have brought out clearly some of the salient features of Icelandic geology. But I will not enter into any discussion on questions of scientific interest, though Dr. Grossmann has provided us with ample material for it. His pictures of the volcanic regions suggest many points on which we might ask for further information, and his illustrations of the peculiar topography of the island might be made the text for a long discourse. He did not himself enter into scientific problems, and his explanations of some of the superficial features might be open to question. It is remarkable to what an extent all over northern Europe such surface-features have given rise to legends of witches, warlocks, and giants. It would be interesting to know how far the 


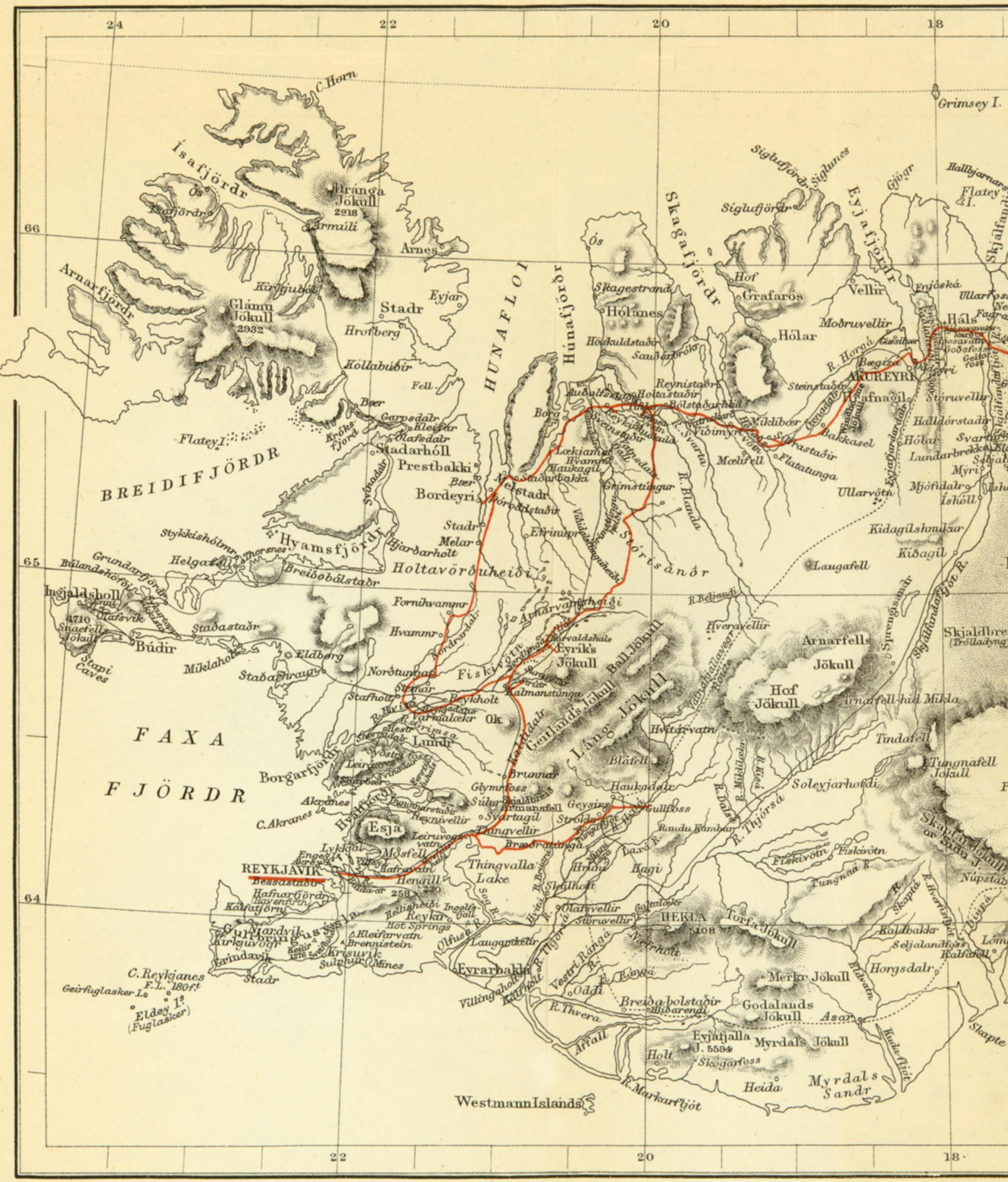

Published by the Royal Geographical Society 
